Pacific Journal of Mathematics

PROXIMATION OF CURVES 


\title{
APPROXIMATION OF CURVES
}

\author{
H. Guggenheimer
}

Generalizing recent results of J. M. Sloss we show: A curve in $n$-space that admits a continuously differentiable first order frame can be $C^{1}$ approximated to any desired accuracy by a continuous, piecewise $C^{r+2}$ curve for which the curvature functions are prescribed $C^{r}(r=0,1, \cdots, \infty, \omega)$ functions of the arc length. The result can be extended to riemannian geometry.

The theorem published by James M. Sloss [4] in this journal to the effect that a regular $C^{3}$ curve can be approximated by a piecewise helix that either is circular or whose curvature or torsion are those of the given curve, can be generalized. The proof can be simplified by an explicit use of Gronwall's inequality [2] which is one of the strongest tools available in the treatment of ordinary differential equations. Gronwall's inequality says that

$$
u(t) \leqq C+\int_{a}^{t} u(\tau) v(\tau) d \tau, t \geqq a, u(t) \geqq 0, v(t) \geqq 0,
$$

implies

$$
u(t) \leqq C \exp \int_{a}^{t} v(\tau) d \tau
$$

We fix a coordinate system in $E^{n}$. Let $a_{i}$ be the unit vector on the $i$ th coordinate axis and

$$
\boldsymbol{a}=\left(\begin{array}{c}
a_{1} \\
\vdots \\
a_{n}
\end{array}\right)
$$

the frame of these vectors. We are given a curve $X(s), 0 \leqq s \leqq L$, as a function of its arc length. We say that $X$ admits a continuously differentiable frame of first order [1] if there exists a continuously differentiable orthogonal matrix function $\Theta(s)$ so that the unit vector $e_{1}(s)=X^{\prime}(s)$ is the first vector of the frame $e=\theta a$. Then $X$ must be a $C^{2}$ curve. Conversely, if $X$ is $C^{2}$, we may define $e$ as the frame on $S^{n-1}$ for which $e_{1}$ is the unit tangent $e_{1}(s) \in S^{n-1} e_{k}(1 \leqq k \leqq n-1)$ is tangent to the equatorial $S^{k-1}$ in the $S^{k}$ defined by $a_{1}, \cdots, a_{k+1}$ and $e_{n}$ is tangent to the meridian. Naturally, if $X$ is $C^{n+1}$, the Frenet frame may be taken as $e$. We put $A(s)=\Theta^{\prime}(s) \Theta(s)^{-1}$.

For matrices we use the sup-norm of the corresponding linear 
transformation. The norm of the frame $e=\Theta a$ shall be the norm of $\Theta$.

THEOREM. $A C^{2}$ curve of finite length can be approximated in the $C^{1}$ topology by a continuous, piecewise differentiable curve for which the curvature functions are prescribed $C^{r}$ functions of the arc length, $r \geqq 0$.

The structure equations of the curve $X$ and the frame $e$ are

$$
\begin{aligned}
X^{\prime}(s) & =e_{1}(s), \\
\boldsymbol{e}^{\prime}(s) & =A(s) \boldsymbol{e}(s),
\end{aligned}
$$

with a continuous matrix $A(s), 0 \leqq s \leqq L$. We want to approximate $X(s)$ by a continuous curve $Y(s)$ so that

$$
\begin{aligned}
Y^{\prime}(s) & =e_{1}^{*}(s), \\
\boldsymbol{e}^{* \prime}(s) & =A^{*}(s) \boldsymbol{e}^{*}(s),
\end{aligned}
$$

except at finitely many points where the equations hold only in the sense of forward one-sided derivatives and where $A^{*}(s)$ is a given (continuous) matrix function of $s$. We shall not use the fact that $A^{*}(s)$ is skew-symmetric and has nonzero entries $a_{i j}^{*}$ only for $j=i \pm 1$ [3].

We put

$$
M=\max \|A(s)\|, N=\max \left\|A^{*}(s)\right\|,
$$

and choose $\Delta s$ subject to

$$
\Delta s \leqq \min \left(N^{-1}, \varepsilon(e(1+L)(M+N))^{-1}\right), \frac{L}{\Delta s} \text { an integer . }
$$

For $k \Delta s \leqq s \leqq(k+1) \Delta s, 0 \leqq k<L / \Delta s$, define $Y(s)$ by

$$
\begin{aligned}
\boldsymbol{e}^{*}(s) & =\boldsymbol{e}(k \Delta s)+\int_{k \Delta s}^{s} A^{*}(\sigma) \boldsymbol{e}^{*}(\sigma) d \sigma, \\
Y(s) & =Y(k \Delta s)+\int_{k \Delta s}^{s} e_{1}^{*}(\sigma) d \sigma, \\
Y(0) & =X(0) .
\end{aligned}
$$

Then

$$
\begin{aligned}
\left\|\boldsymbol{e}^{*}(s)-\boldsymbol{e}(s)\right\| & =\left\|\int_{k \Delta s}^{s}\left(A^{*} \boldsymbol{e}^{*}-A \boldsymbol{e}\right) d \sigma\right\| \\
& \leqq \int_{k \Delta s}^{s}\left\|A^{*}-A\right\|\|\boldsymbol{e}\| d \sigma+\int_{k \Delta s}^{s}\left\|A^{*}\right\|\left\|\boldsymbol{e}^{*}-\boldsymbol{e}\right\| d \sigma
\end{aligned}
$$




$$
\leqq(M+N) \Delta s+N \int_{k \Delta s}^{s}\left\|e^{*}-\boldsymbol{e}\right\| d \sigma
$$

By Gronwall's inequality,

$$
\begin{aligned}
\left\|e^{*}(s)-e(s)\right\| & \leqq(M+N) \Delta s \exp (N(s-k \Delta s)) \\
& \leqq(M+N) e \Delta s \leqq \varepsilon /(1+L) .
\end{aligned}
$$

Hence,

$$
\begin{aligned}
|Y(s)-X(s)| & \leqq|Y(k \Delta s)-X(k \Delta s)|+\int_{k \Delta s}^{s}\left|e_{1}^{*}(\sigma)-e_{1}(\sigma)\right| d \sigma \\
& \leqq|Y(k \Delta s)-X(k \Delta s)|+\int_{k \Delta s}^{s}|| \boldsymbol{e}^{*}(\sigma)-\boldsymbol{e}(\sigma)|| d \sigma \\
& \leqq|Y(k \Delta s)-X(k \Delta s)|+\varepsilon \Delta s(L+1)^{-1} \cdot
\end{aligned}
$$

By induction, $|Y(k \Delta s)-X(k \Delta s)| \leqq \varepsilon k \Delta s(1+L)^{-1}$ and

$$
\begin{gathered}
|Y(s)-X(s)| \leqq \varepsilon L(1+L)^{-1}, \\
|Y(s)-X(s)|+\left|Y^{\prime}(s)-X^{\prime}(s)\right| \leqq \varepsilon \frac{L}{1+L}+\varepsilon \frac{1}{1+L}=\varepsilon .
\end{gathered}
$$

The same argument would hold for a matrix $A^{*}(s)$ with bounded, integrable entries if the differential equations are supposed to hold a.e., in the sense of Caratheodory. For $C^{r}$ entries, $Y$ is a $C^{r+2}$ curve. Since the structure of the matrices was not used, the same argument holds for riemannian or Minkowski geometry.

\section{REFERENCES}

1. E. Cartan, La méthode du repère mobile, la théorie des groupes continus et les espaces généralisés, ASI 194, Paris, Hermann 1935.

2. T. H. Gronwall, Note on the derivatives with respect to a parameter of the solution of a system of differential equation, Ann. of Math., 20 (1918), 292-296.

3. H. Guggenheimer, Differential Geometry, New York, McGraw-Hill, 1963.

4. J. M. Sloss, The bending of space curves into piecewise helical curves, Pacific J. Math., 32 (1970), 231-239.

Received October 23, 1970. Research partially supported by NSF Grant GP-19133.

PolyteChNic INSTitute of BRoOKLyN 



\title{
PACIFIC JOURNAL OF MATHEMATICS
}

\section{EDITORS}

\author{
H. SAMELSON \\ Stanford University \\ Stanford, California 94305 \\ C. R. HobBY \\ University of Washington \\ Seattle, Washington 98105
}

J. DugundJI

Department of Mathematics

University of Southern California

Los Angeles, California 90007

RICHARD ARENS

University of California

Los Angeles, California 90024

\section{ASSOCIATE EDITORS}
E. F. BECKENBACH
B. H. NeumanN
F. WOLF
K. YOSHIDA

\section{SUPPORTING INSTITUTIONS}

\author{
UNIVERSITY OF BRITISH COLUMBIA \\ CALIFORNIA INSTITUTE OF TECHNOLOGY \\ UNIVERSITY OF CALIFORNIA \\ MONTANA STATE UNIVERSITY \\ UNIVERSITY OF NEVADA \\ NEW MEXICO STATE UNIVERSITY \\ OREGON STATE UNIVERSITY \\ UNIVERSITY OF OREGON \\ OSAKA UNIVERSITY
}

\author{
UNIVERSITY OF SOUTHERN CALIFORNIA \\ STANFORD UNIVERSITY \\ UNIVERSITY OF TOKYO \\ UNIVERSITY OF UTAH \\ WASHINGTON STATE UNIVERSITY \\ UNIVERSITY OF WASHINGTON
AMERICAN MATHEMATICAL SOCIETY
NAVAL WEAPONS CENTER

The Supporting Institutions listed above contribute to the cost of publication of this Journal, but they are not owners or publishers and have no responsibility for its content or policies.

Mathematical papers intended for publication in the Pacific Journal of Mathematics should be in typed form or offset-reproduced, (not dittoed), double spaced with large margins. Underline Greek letters in red, German in green, and script in blue. The first paragraph or two must be capable of being used separately as a synopsis of the entire paper. The editorial "we" must not be used in the synopsis, and items of the bibliography should not be cited there unless absolutely necessary, in which case they must be identified by author and Journal, rather than by item number. Manuscripts, in duplicate if possible, may be sent to any one of the four editors. Please classify according to the scheme of Math. Rev. Index to Vol. 39. All other communications to the editors should be addressed to the managing editor, Richard Arens, University of California, Los Angeles, California, 90024.

50 reprints are provided free for each article; additional copies may be obtained at cost in multiples of 50 .

The Pacific Journal of Mathematics is published monthly. Effective with Volume 16 the price per volume (3 numbers) is $\$ 8.00$; single issues, $\$ 3.00$. Special price for current issues to individual faculty members of supporting institutions and to individual members of the American Mathematical Society: $\$ 4.00$ per volume; single issues $\$ 1.50$. Back numbers are available.

Subscriptions, orders for back numbers, and changes of address should be sent to Pacific Journal of Mathematics, 103 Highland Boulevard, Berkeley, California, 94708.

\section{PUBLISHED BY PACIFIC JOURNAL OF MATHEMATICS, A NON-PROFIT CORPORATION}

Printed at Kokusai Bunken Insatsusha (International Academic Printing Co., Ltd.), 270, 3chome Totsuka-cho, Shinjuku-ku, Tokyo 160, Japan. 


\section{Pacific Journal of Mathematics}

\section{Vol. 40, No. $2 \quad$ October, 1972}

Louis I. Alpert and L. V. Toralballa, An elementary definition of surface area in $E^{n+1}$ for smooth surfaces...........................

Eamon Boyd Barrett, A three point condition for surfaces of constant mean curvature........................................

Jan-Erik Björk, On the spectral radius formula in Banach algebras ....... 279

Peter Botta, Matrix inequalities and kernels of linear transformations . . . . 285

Bennett Eisenberg, Baxter's theorem and Varberg's conjecture ........... 291

Heinrich W. Guggenheimer, Approximation of curves .............. 301

A. Hedayat, An algebraic property of the totally symmetric loops associated with Kirkman-Steiner triple systems ....................... 305

Richard Howard Herman and Michael Charles Reed, Covariant representations of infinite tensor product algebras ................

Domingo Antonio Herrero, Analytic continuation of inner

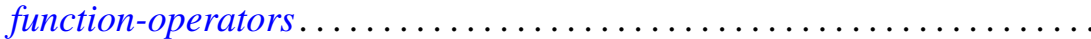

Franklin Lowenthal, Uniform finite generation of the affine group......... 341

Stephen H. McCleary, 0-primitive ordered permutation groups .......... 349

Malcolm Jay Sherman, Disjoint maximal invariant subspaces .......... 373

Mitsuru Nakai, Radon-Nikodým densities and Jacobians .............. 375

Mitsuru Nakai, Royden algebras and quasi-isometries of Riemannian manifolds. . .

Russell Daniel Rupp, Jr., A new type of variational theory sufficiency

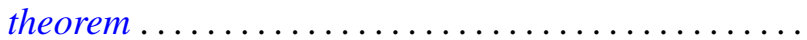

Helga Schirmer, Fixed point and coincidence sets of biconnected multifunctions on trees..........................

Murray Silver, On extremal figures admissible relative to rectangular

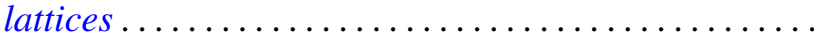

James DeWitt Stein, The open mapping theorem for spaces with unique segments ...

Arne Stray, Approximation and interpolation

Donald Curtis Taylor, A general Phillips theorem for $C^{*}$-algebras and some applications

Florian Vasilescu, On the operator $M(Y)=T Y S^{-1}$ in locally convex algebras...

Philip William Walker, Asymptotics for a class of weighted eigenvalue problems...

Kenneth S. Williams, Exponential sums over $\mathrm{GF}\left(2^{n}\right)$. 